3. Ігнатишин В.В., Іжак Т.Й. Астрофізичні аспекти сейсмотектонічного стану Закарпатського внутрішнього прогину. Актуальні проблеми регіональних досліджень. Матеріали II Міжнародної науково-практичної науково-практичної інтернет-конференції. 17-18 травня 2018 року. м. Луцьк. С. 215-219.

4. Ігнатишин А.В., Ігнатишин М.Б., Ігнатишин В.В. Геофізичні поля та геомеханічні процеси в Закарпатському внутрішньому прогині. $\mathrm{X}$ наукова конференція молодих вчених та спеціалістів „Геологія i геологія горючих копалин,, присвячена, 100 річчю НАН України. 19-20 вересня 2018 року. 1-2(174-175) 2018. м. Львів. С. 81-84. ISSN 0869-0774

5. Ігнатишин В.В. Просторово-часовий розподіл сейсмічності Закарпатського внутрішнього прогину. Матеріали Міжнародної наукової конференції. Географічна наука та освіта : від констатації та конструктивізму, 28-29 вересня 2018 року м. Київ, Україна. Присвячена 100-річчю Національної академії наук України. Зб. наук. праць. К., 2018. C. 76-78.

DOI https://doi.org/10.30525/978-9934-26-111-4-35

\title{
STRUCTURE AND CURRENT CONDITION OF SOILS IN THE KOROSTEN DISTRICT OF ZHYTOMYR REGION
}

\author{
Kostiuk V. S. \\ Candidate of Biological Sciences, \\ Senior lecturer at the Department Ecology and Geography \\ Zhytomyr Ivan Franko State University \\ Korinnyi V. I. \\ Candidate of Geographic Sciences, \\ Associate Professor at the Department Ecology and Geography \\ Zhytomyr Ivan Franko State University \\ Zhytomyr, Ukraine
}

The Korosten district is located in the northern part of the Zhytomyr region, within the Central Polissia, in the zone of mixed forests. Its area is $1764 \mathrm{~km}^{2}$ and it occupies $6 \%$ of the region's territory.

There is significant variegation of the soil cover due to the heterogeneity of the relief, the variety of rocks lying on the surface and the diversity of the 
flora, which have changed throughout geological history. As a result of the developing process of podzolic, soddy and bog soil formation, sod-podzolic, sod-podzolic gley and soddy soils were formed in the Korosten district.

Most soils have built upon a thin layer of sedimentary rocks, mainly of light size-grad composition, overlying a thick layer of rocks of the Ukrainian crystalline shield. Soddy-podzolic, clayey-sandy, soddy-podzolic sandy loam, soddy-podzolic gley, soddy-podzolic gley sandy loam, soddy-podzolic highly clayey soils with humus and pitot content (less than 2\%) developed in flat, non-boggy places. Sod soils prevail in gullies and river valleys; boggy and peat-boggy soils with a humus content of up to $3 \%$ have formed in floodplains and depressions of the relief. You can find light gray forest soils in some areas covered with mixed forest, in some places. Almost all these soils are highly acidic, retain moisture poorly, or, conversely, some of them are constantly wetland.

Fortunately, the current condition of soils in the Korosten district as well as in the Zhytomyr region as a whole cannot yet be by no means dramatic. But those negative environmental processes observed in the world have a significant impact on them. Anthropogenic impact, irrational use and erosion processes, deterioration of the soil structure, mechanical destruction and compaction of the soil, constant depletion of humus and nutrients, soil pollution with agrochemicals, waterlogging and salinity of lands cause an increase in degradation processes.

According to researchers, one of the main factors in terms of scale, which leads to land degradation in the region, is their radioactive contamination after the Chernobyl disaster (mainly ${ }^{137} \mathrm{Cs}$ and ${ }^{90} \mathrm{Sr}$ ). The average density of ${ }^{90} \mathrm{Sr}$ contamination is $0.02-0.15 \mathrm{Ki} / \mathrm{km}^{2}$, and ${ }^{137} \mathrm{Cs}$ is $1-5 \mathrm{Ki} / \mathrm{km}^{2}$.

The next factor, in terms of the volume of impact on the degradation processes of the soil cover, is erosion. According to the State Statistics Service of Ukraine, the area in the Korosten district, which is subject to erosion processes, is 1.1 thousand hectares (1.3\% of agricultural land).

One more crucial problem is the use of mineral fertilizers and chemical plant protection products accompanied by soil pollution with ballast substances (sulphates, chlorides) and pesticide storage in soils and groundwater. Almost all soils are highly acidic, retain moisture poorly, or, conversely, some of them are constantly wetland. They require liming, and wetland requires draining in most cases.

The Zhytomyr region is rich enough in mineral deposits, which are actively developed (mainly by open-cut), which leads to an active expansion of areas with disturbed lands. Experts point to the degradation of zonal soils 
and underlying parent rocks, the destruction of the fertile humus-residual soil horizon, root systems of trees, waterlogging of the territory, changes in the level of groundwater, destruction of forest resources, changes in the migration processes of the region's fauna, if we speak about the consequences of mining widespread in the area of granite, labrodorite and gabbro, in particular. Nowadays, disturbed lands dumps of overburden and waste cause a significant environmental problem and require the development of a set of measures aimed at solving it.

Thus, the protection of land resources from degradation processes is becoming one of the most significant issues of the region. Anthropogenic impact, irrational use and erosion cause deep and, sometimes, irreparable damage to the soil.

It is necessary to conduct rationally sound economic activities, constantly monitor soils to display their current condition to preserve the region's soils. Now, the priority for the Zhytomyr region is afforestation of unproductive and unsuitable for agricultural use lands, forest reclamation protection of arable land from erosion, protection of water bodies, fixing the surface of ravines and sands, as well as combating the local developing erosion process.

\section{References:}

1. Балюк С.А., Медведєв В.В., Мірошниченко М.М., Скрильник Є.В., Тимченко Д.О., Фатєєв А.І., Христенко А.О., Цапко Ю.Л. Екологічний стан грунтів України. Украӥнський географічний журнал. 2012. № 2. C. 38-42.

2. Легенька Т.П. Причини деградації грунтів Житомирської області та шляхи відновлення їх продуктивності. Вісник ЖНАЕУ. 2009. № 2. C. 376-383.

3. Макаренко В.В., Матвієнко Б.Я. Вплив антропогенного навантаження на стан родючості грунтів на прикладі Коростенського району Житомирської області. Молодий вчений. 2016. № 5. С. 314-317.

4. Яцук І.П. Аналіз агроекологічного стану грунтів Житомирської області за допомогою методики еколого-агрохімічної паспортизації. Збалансоване природокористування. 2014. № 2. С. 107-110.

5. Регіональна доповідь про стан навколишнього природного середовища Житомирської області у 2019 році. URL: http://ecology.zt.gov.ua/StanDov_reg_dop_menu.html (дата звернення: 24.06.2021). 